\section{All-on-4 treatment of an edentolous patient after autogenous grafting}

\section{Total dişsiz bir hastanın otojen greftleme sonrası All-on-4 konsepti ile tedavisi}

\author{
Assist. Prof. Sercan Küçükkurt \\ Istanbul Aydın University, Faculty of Dentistry, \\ Department of Oral and Maxillofacial Surgery, \\ Istanbul \\ Orcid ID: 0000-0002-4095-957X
}

Assist. Prof. Meryem Gülce Subaşı

Istanbul Aydın University, Faculty of Dentistry, Department of Prosthodontics, Istanbul

Orcid ID: 0000-0002-2510-9745

Received: 24 December 2017

Accepted: 3 April 2018

doi: 10.5505/yeditepe.2019.79553

\section{Corresponding author}

Assist. Prof. Sercan Küçükkurt

Istanbul Aydın University, Faculty of Dentistry, Department of Oral and Maxillofacial Surgery

Beşyol Mah. İnönü Cad. Akasya Sk. No:6

Sefaköy/Küçükçekmece/Istanbul

Phone: +905326205590

E-mail: skucukkurt@gmail.com

\section{SUMMARY}

All-on-4 concept is a treatment method for fixed prosthetic rehabilitation of edentulous jaws with a total of four dental implant, two anterior vertically placed and two posterior inclined implants, supported full arch hybrid prosthetic restorations. It has been reported that inclined implants placed to the posterior region can provide better biomechanical strength, reduced size of prosthetic cantilever extensions, without anatomic limitations and no need for further surgical procedures.

Many studies have shown that after the loss of teeth, bone resorption in the jaws is seen more intensely in the posterior regions. All-on- 4 treatment concept is usually preferred because of the anatomical limitations of the maxillary sinuses in the posterior maxilla and inferior alveolar nerve in the mandible. Thus, advanced surgical procedures such as bone augmentation in the posterior region are avoided. However, over time resorption in the posterior regions begins to accompany with horizontal resorption of the anterior region. In this case, surgical procedures to increase the bone volume are inevitable to maintain the existing vertical crest height and to be able to provide an implant-supported treatment to the region.

In this case report, a 68-year-old female patient, who has edentulous maxilla and only canine teeth in mandible, was treated by grafting anterior maxilla with autogenous bone block grafts obtained from mandibular symphysis, and then the rehabilitation of both jaws prosthetically according to the All-on-4 concept was done. There was no complication in follow-up of the patient for 2 years and there was no bone loss in the periimplant bone except physiologically accepted levels. Thanks to this application, the aesthetic and functional expectations of the patient are met.

Keywords: All-on-4, dental Implant, autogenous grafting, bone graft, symphysis.

\section{ÖZET}

All-on-4 tedavi konsepti, anterior bölgeye iki adet dik ve posterior bölgeye iki adet eğimli yerleştirilen, toplam dört implant destekli, tek parça, tüm ark protez uygulamasını içeren, tam dişsiz çenelerin sabit protetik rehebilitasyonu için uygulanan bir tedavi metodudur. Yapılan çalışmalarda, posterior bölgeye eğimli yerleştirilen implantların ileri cerrahi işlemlere gerek kalmadan anatomik sınırlamalara takılmadan uygulanabildiği, biyomekanik kuvvetleri daha iyi karşıladığı, protetik kantilever uzantıların boyutunu azalmasını sağladığı ve ayrıca başarısızlık oranlarında dik yerleştirilen implantlarla karşılaştırıldığında anlamlı bir fark bulunmadığı bildirilmektedir.

Dişlerin kaybının ardından çenelerde kemik rezorpsiyonunun posterior sahalarda daha şiddetli görüldügü yapılan birçok çalışmada gösterilmiştir. All-on-4 tedavi protokolü de genellikle üst çenede posterior bölgede maksiller sinüs, mandibulada ise inferior alveolar sinir kaynaklı anatomik sınırlamalar nedeniyle tercih edilmektedir. Böylelikle posterior bölgede kemik augmentasyonu gibi ileri cerrahi işlemlerden kaçınılmaktadır. Ancak uzun yıllar süren dişsizlikle birlikte posterior bölgedeki 
rezorpsiyona, anterior bölgede ilk etapta horizontal bölgedeki rezorpsiyonda eşlik etmeye başlar. Bu durumda karşısında mevcut vertikal kret yüksekliğini korumak ve bölgeye implant destekli bir tedavi yapabilmek için kemik hacmini arttırmaya yönelik işlemler kaçınılmaz olmaktadır. Bu olgu sunumunda, üst çenesi total dişsiz, alt çenede ise yalnızca kanin dişleri bulunan ve ögürrme refleksi nedeniyle üst total protezini takmakta zorlanan 68 yaşındaki bayan hastada, öncelikle maksilla anterior bölgenin, mandibula simfiz bölgesinden elde edilen blok kemiklerle greftlenmesi ve sonraki süreçte her iki çenenin All-on-4 konsepti ile rehabilitasyonu ve vakanın 2 yıllık takibi rapor edilmektedir.

Anahtar kelimeler: All-on-4, dental implant, otojen greftleme, kemik grefti, simfiz.

\section{INTRODUCTION}

The use of osseointegrated dental implants for the treatment of edentulousness is based on Brånemark's works 60 years ago.' From that time on, day-to-day, dental implants have become the first choice among alternative treatment options for compensating missing teeth in contemporary dentistry. Although there are several alternative treatment approaches that provide relatively similar comfort levels for the restoration of partial edentulous patients, the implementation of implant-supported fixed prosthesis in the restoration of complete edentulous jaws is a revolutionary feature. ${ }^{2}$ Among the concepts proposed over time for the rehabilitation of total edentulous patients and suggesting up to 10 implants for a single jaw ${ }^{3}$, the Allon-4 treatment concept, which offers the promise of rehabilitating edentulous jaw with only 4 implants, has come to the forefront as a highly ambitious technique. ${ }^{4-6}$

The design of the All-on-4 concept was first applied to the mandible in 2003 by Malo et al.7 At first, based on the knowledge obtained from earlier in silico analyzes that angled abutments and implants cause higher stress on the bones, this approach has been not easily convinced. ${ }^{8}$ However, in many recent studies on more detailed and specific models for this protocol, the feasibility of 2 flat and 2 inclined implant placement has been confirmed and reported to be even superior to conventional methods. ${ }^{9,} 10$ Subsequently, with the introduction of new evidences, the number of studies that dictate the use of as many implants as possible in a cantilever has begun to decrease. ${ }^{11}$ In 2005, All-on-4 concept was adapted by Malo et al. ${ }^{12}$ to maxilla based on concepts the success on mandible. In the following period, the success of this concept was supported by many other researches for both jaws. Many studies have shown that bone resorption in the jaws after tooth loss is more severe in the posterior areas. ${ }^{13}$ Allon- 4 concept is usually preferred because of the limitations of maxillary sinus in the maxilla and inferior alveolar nerve in the mandible. Thus, advanced surgical procedures such as bone augmentation in the posterior region are avoided. ${ }^{4,5}{ }^{5}{ }^{14}$ However, over time, resorption in the posterior region, is accompanied by horizontal resorption in the anterior region..$^{13}$ In these cases, procedures to increase the bone volume are inevitable in order to maintain the existing vertical crest height and to make an implant-supported treatment in the region. As a matter of fact, later grafting of the region following vertical bone loss in the anterior area becomes very difficult, and zygomatic implants are almost the only alternative of this option. ${ }^{15,16}$

In this case report, a 68-year-old female patient, who has edentulous maxilla and only canine teeth in mandibula, was treated by grafting anterior maxilla with autogenous bone block grafts obtained from mandibular symphysis, and then the rehabilitation of both jaws prosthetically according to the All-on-4 concept was done. Thus, while high success rates are reported in implants applied after autogenous block grafting in the literature, there is limited information about application of All-on-4 concept to the block grafted bone.

\section{CASE REPORT}

A 68-year-old female patient with no systemic diseases, who has edentulous maxilla and only canine teeth in mandibula, was admitted to our department with complaint of difficulty in using her total prosthesis because of gag reflex and mobility in teeth that support the lower partial prosthesis.

Following the clinical examination, it was decided to take CBCT to view the patient's bone volume in more detail. CBCT images of the patient showed significant bone loss in the mandibular posterior region, especially in the vertical direction, despite the presence of adequate bone to allow placement of the dental implants to the anterior mandible. The maxilla of the patient was found to be extremely atrophic that would not allow implant placement both anterior and posterior regions (Figure 1).

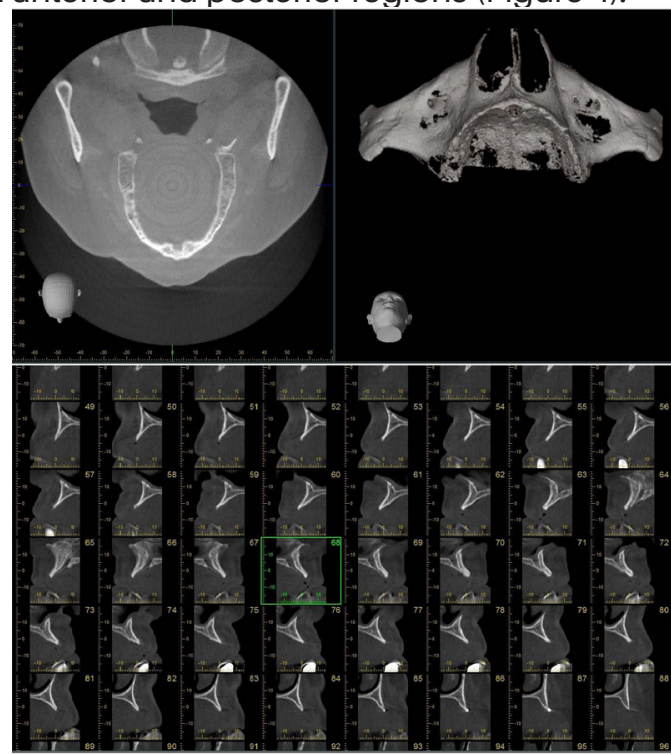

Figure 1. Pre-operative CBCT images of patient's atrophic maxilla. 
Six different treatment options were proposed to the patient and these plans were discussed in detail. These plans are:

1. New lower-upper conventional prosthesis

2. Two implant supported locator system prosthesis for both jaws

3. Two implant supported locator system prosthesis for lower jaw, autogenous block grafting to the maxilla and then locator system prosthesis supported by four implants

4. Autogenous block grafting to the maxilla and fixed prostheses with All-on-4 concept on both jaws

5. All-on-4 concept for lower jaw and upper jaw quadruple zygoma implant supported fixed prosthesis

6. Total autogenous grafting of both jaws with bone blocks from the iliac region, double sided sinus lifting, followed by a total of 12 implant placement.

In the interviews with the patient, factors such as treatment processes, risks, failure rates, total treatment durations, and financial dimensions were evaluated in detail for both parties. The patient stated that she wanted to have permanent implant-supported dentures for both jaws because of the presence of severe gag reflex. For this reason, she rejected the first 3 treatment plans proposed. Zygomatic implants have not been accepted because of concerns raised by the treatment concept in the patient and family. Iliac grafts and 12 implants were not accepted because of the long duration of treatment, costs, and the involvement of multiple interventional therapies and therefore the risk factors involved in the procedure.

As a result, it was decided that the patient should be grafted to the maxillary anterior region with the help of the bone blocks to be gained from the mandibular symphysis area and to placement of implants according to All-on-4 concepts for both jaws after the healing period.

\section{Surgical Phase}

In appropriate sterile conditions, a single horizontal incision made through the anterior sulcus area of the mandible under local anesthesia resulted in the elevating of the mucoperiosteal flap between both mental foramens and the bone has been reached. In order to protect the mental foramens, the field of view was provided for the foramen and before operation, on the CBCT, the anterior loops of the mental nerve were identified and the incision areas were made according to these conditions. Bone blocks were prepared under water cooling with a fine fissure bur. By considering the reduction of bone defect in the region, the block bone grafts were designed into two parts and a bone bridge between the blocks were left in the donor site. Cortical blocks were removed with the aid of osteotomes and trabecular bones on the base were collected with the help of a curette. In order to provide control of hemorrhage in the region, collagen hemostatic sponges in the form of blocks were placed and the mental muscle fibers were sutured with resorbable sutures and then the mucosa was closed with silk suture.

After local anesthesia, the mucoperiosteal flap was raised in the anterior region of the maxilla and two block grafts of about $1 \times 3 \mathrm{~cm}$ in size were placed just in front of the maxillary sinuses, with the idea of placing the inclined implants as posteriorly as possible. Blocks are fixed with the help of mini bone fixation screws. Trabecular bones were filled in the cavities and $2 \mathrm{cc}$ xenografts (Apotos Mix, Osteobiol Tecnoss Dental Srl., Torino, Italy) were applied on the block grafts to limit the resorption of the autogenous block grafts and $25 \times 30 \mathrm{~mm}$ collagen membranes (Evolution 25x35 mm Oval, Osteobiol Tecnoss Dental Srl., Torino, Italy) placed on each side. Then flaps were sutured. (Fig. 2)
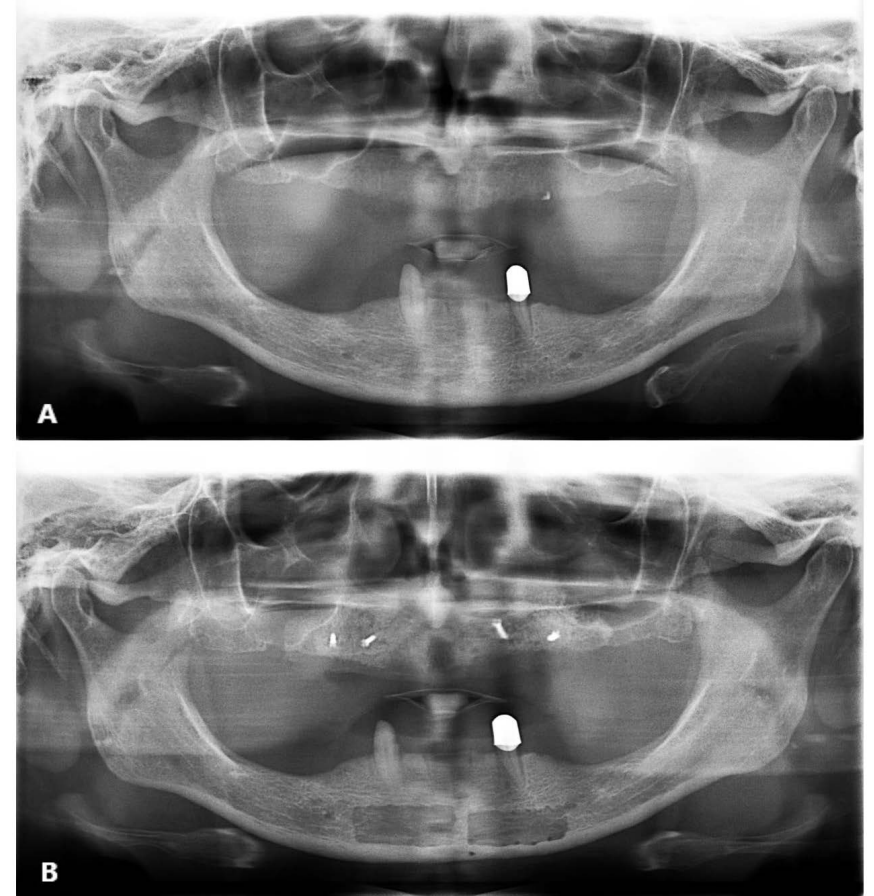

Figure 2. A. Preoperative orthopantomography, B. Orthopantomography after bone grafting procedure.

The patient refused to use a temporary removable prosthesis because of her gag reflex, and she demanded to remain edentulous during the healing period.

After a 4-month healing period (Fig. 3, 4), four MIS C1 (MIS Implant Technologies, Dentsply-Sirona, Salzburg, Osterreich) implants were placed to each jaw, according to Allon-4 treatment concept. 

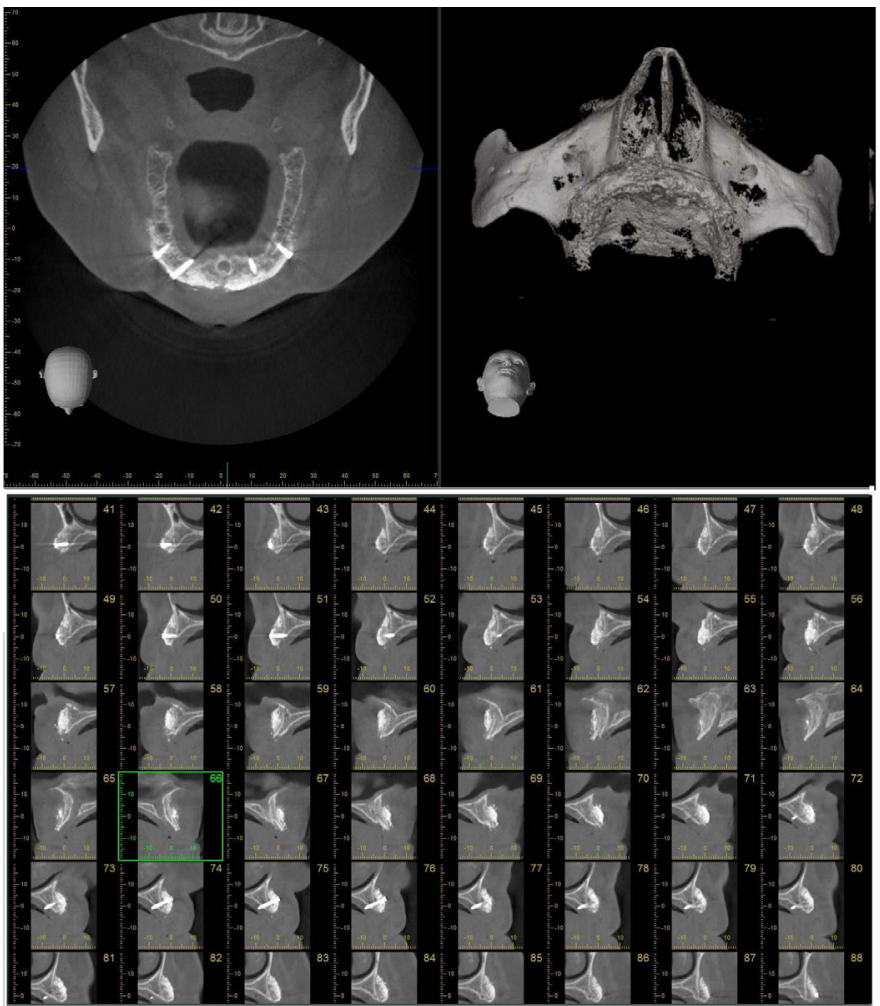

Figure 3. СВСТ images of patient's maxilla 4 months after grafting procedure.
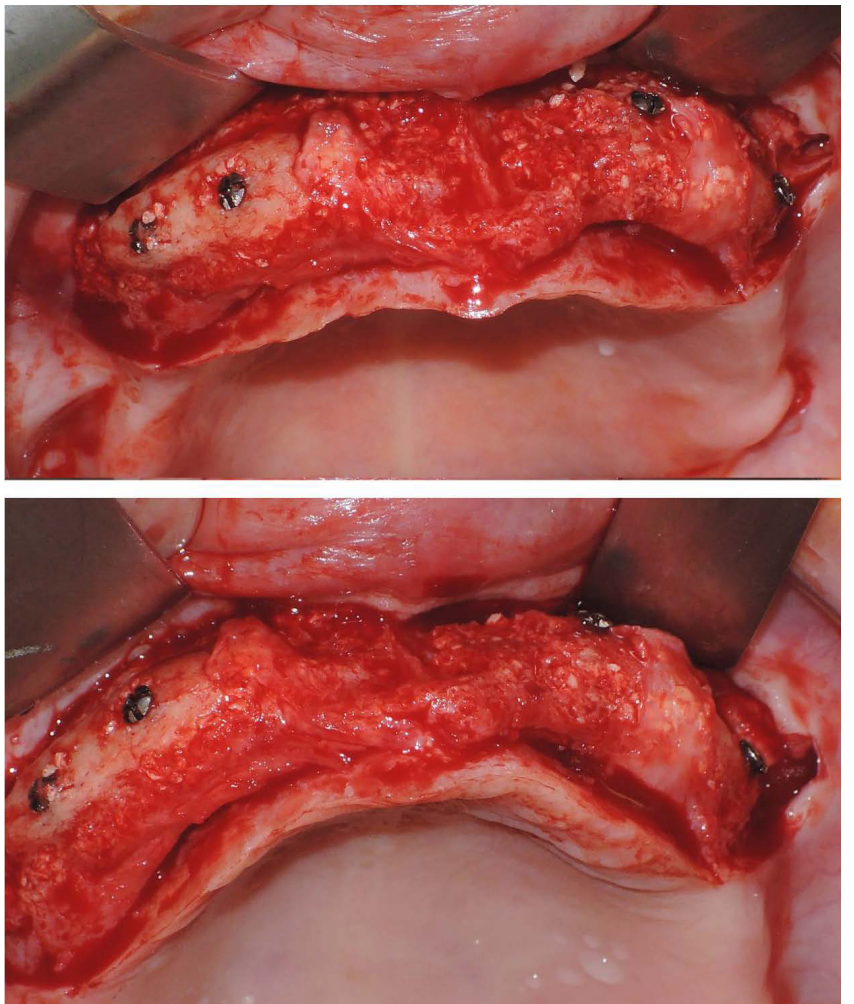

Figure 4. Intraoral photography of patient's maxilla 4 months after grafting procedure.

Four implants placed vertically for the lower and upper jaws in the anterior region are $4.2 \times 11.5 \mathrm{~mm}$ in size. $\mathrm{Ri}-$ ght maxillary inclined implant is $4.2 \times 10 \mathrm{~mm}$ in dimension and the other 3 inclined implants are $4.2 \times 13 \mathrm{~mm}$. Immediate prosthesis loading protocol was not applied because adequate values (70 and above) were not obtained in ISQ measurements made with Osstell device (Osstell Company, Gothenburg, Sweden) especially on implants applied to maxillary grafted bones. Cover screws were placed on the implants and allowed to heal for 3 months. (Figure 5A) Gingiva formers were placed on the implants after a 12-week healing period, and patient was directed to the department of prosthodontics after healing period.
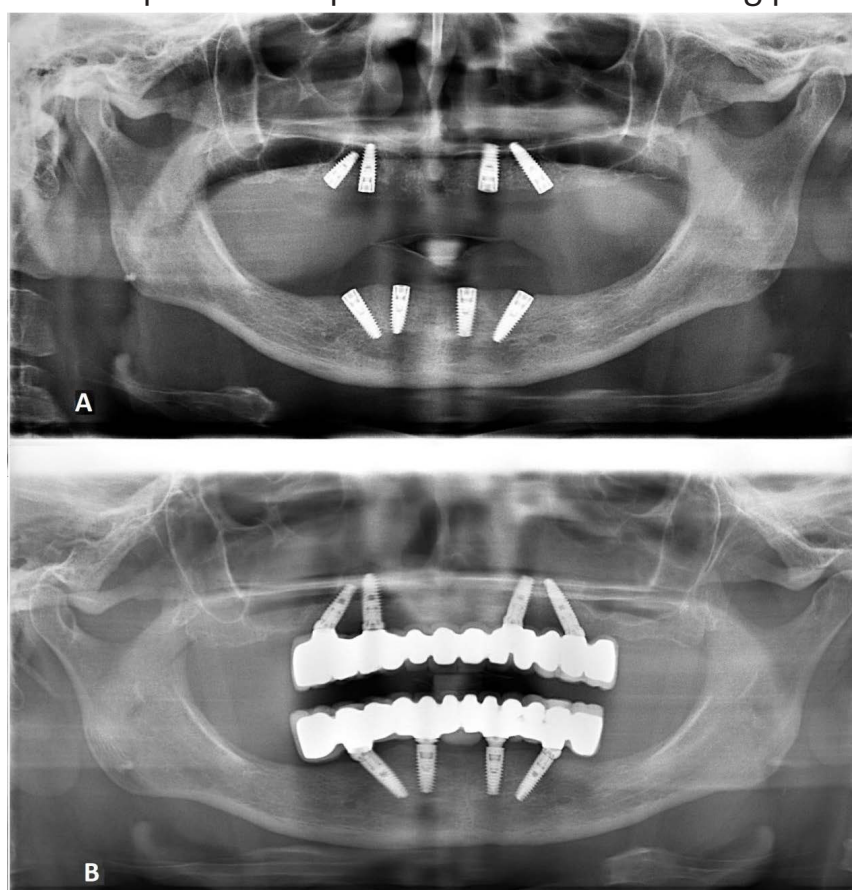

Figure 5. A. Orthopantomography after implant placement, B. 2-year follow-up Orthopantomography.

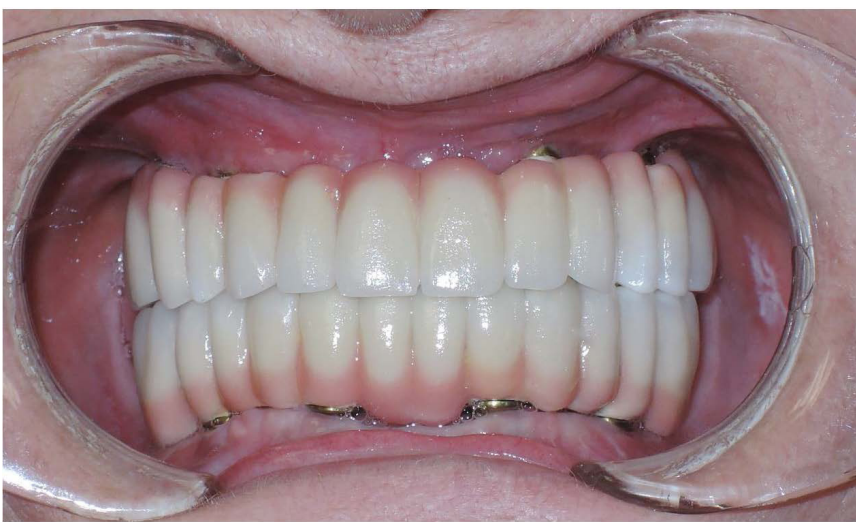

Figure 6. Intraoral photography of the patient after prosthetic rehabilitation.

\section{Prosthetic Phase}

In the first prosthodontics appointment, after removing the healing caps the anatomic impressions of both jaws were made. Acrylic base plates and wax rims were prepared on the plaster models. The vertical dimension and centric occlusion were determined using the wax rims and then, they were mounted on the articulator. Following that, the multi-unit abutments (straight or angled) were selected with the aid of wax rims. Therefore, 2 straight multiunit abutments ( 32 and 42 implant) and 6 angled multi-unit abutments were chosen.

In the second appointment, after removing the healing caps denture setup was performed. Vertical dimension, centric relationship and occlusion was controlled. In the same appointment straight, multi-unit abutments were fixed to the implants (32 and 42) using a straight multi-unit ratchet key and angled multi-unit abutments (17 or 30 
degree) were fixed to the remaining implants using an angulated multi-unit key. Straight multi-unit abutments were torqued to the implants at $30 \mathrm{~N}$ and angulated multi-unit abutments were torqued to the implants at $20 \mathrm{~N}$ using a torque ratchet according to the manufacturer's recommendations. Impression copings that were used for closed tray impression procedure were inserted on the multi-unit abutments. Silicone impressions were taken from maxillary and mandibular arches using individual trays. After the impression had set, impression copings were detached from the multi-unit abutments, they were screwed to the multi-unit analogs and then they were inserted in the impression. After these procedures, healing caps had been mounted on the multi-unit abutments.

The impressions and denture setup were sent to the laboratory. The laboratory took a silicone index from the denture setup. Therefore, the technician constructed both the metal framework and porcelain as based on this silicone index. In the laboratory plaster models were obtained from the impressions. Plastic burn-out cylinders were screwed on the multi-unit analogs. The wax framework was modelled on the plastic cylinders as based on the silicone index that had been obtained before. Shortened arc concept with 12 units for maxillary and 12 units for mandibular metal supported ceramic fixed prostheses was designed for the patient. The cantilever length in upper and lower jaws were made in minimal values to minimize the risk of hybrid prostheses fracture. The wax framework was casted from Cr-Co alloy in an induction casting machine. After casting, metal framework was screwed on the multi-unit analogs and sent to the clinic. In the clinic, the metal framework was controlled on the multi-unit abutments for passive fit.

In the following appointment, the fit and balance of the metal supported porcelain hybrid restoration on the multi-unit abutments was checked before it screwed to the multi-unit abutments. Firstly, centric occlusion and then, occlusion in lateral and protrusive movements were checked and adapted. The group balanced occlusion was made in the working side of the mandible. Then, the esthetic visibility of the restorations was corrected. After all corrections, stain and glaze firing was performed. After glazing of restorations, full arch hybrid screw retained metal supported ceramic fixed prostheses were screwed to the multi-unit abutments up to $25 \mathrm{~N}$ according to manufacturer recommendations. Then the, access holes of the restorations were filled with composite resin (Tetric N Ceram, Ivoclar Vivadent, Schaan, Liechtenstein), light cured for 20 seconds using a light curing device (Elipar S10, 3M ESPE, St. Paul, MN, USA) and polished with rubbers. (Figure 6) At the end of the treatment, oral hygiene procedures were explained to the patient. The patient was recalled after 2 years. She was very satisfied with her prostheses in terms of esthetic, function and phonation (Figure 5B).

\section{DISCUSSION}

One of the applications recommended by Brånemark for the use of dental implants in the treatment of posteriorly atrophic edentulous jaws, 4-6 vertically implant placement to the anterior region and posterior cantilever extensions. Although successful results have been obtained from this application for ten years $(78.3 \%$ to $80.3 \%$ for maxilla and $88.4 \%$ to $93.2 \%$ for mandible), it has been reported that due to the very large size of the cantilever extensions required to provide adequate dentition, it causes various problems. ${ }^{14}$ For atrophic jaws, alternative treatment options are also available, such as bone grafting applications, sinus lifting prior to implant placement in the posterior region, or zygoma implants. However, all these procedures cause comorbidities, requirement for additional operations, costs, and extended treatment time that leading to a major obstacle to the preference of these procedures. Also, inferior alveolar nerve lateralization has been abandoned by many physicians because of the high risk of paresthesia in the mandible. ${ }^{14}$

In recent years, depending on such factors, the concept of inclined distal implants has been studied that allows implants to be positioned more posteriorly in order to reduce the length of the cantilever. The inclined placement of distal implants has been suggested to provide a number of biomechanical and clinical advantages for fixed restorations with less invasive techniques, compared with traditional vertical implants and graft procedures. Some of those; Implants can be placed bicortically, in longer lengths, allow more stable anterior-posterior distribution of implants and prosthesis, shorten the cantilever extensions to provide balanced load distribution, and reduce biomechanical complications such as prosthetic fractures. $^{12,14,17-19}$

The All-on-4 treatment concept was developed in 2003 by Malo et al. ${ }^{7}$ is a treatment method proposed for use in the fixed prosthetic rehabilitation of full edentulous jaws. This treatment concept can be defined as a single piece total fixed prosthesis application with support of four dental implants, two vertically in the anterior region and two inclined in posterior regions., ${ }^{72}$ Over the past decade, there has been an increase in the number of scientific studies documenting the clinical performance of the concept following the increasingly widespread clinical use of the All-on-4 treatment concept. Following the long-term successful results published by Malo et al. ${ }^{20}$, many other authors have confirmed the high success rates associated with the use of this protocol. Galindo and Butura ${ }^{21}$ reported that 183 patients were treated with All-on-4 concepts and that only 1 implant ( $99.86 \%$ success rate) failed. Babbush et al. ${ }^{22}$ reported a survival rate of $99.6 \%$ following a 
29.6-month follow-up for 708 implants placed to complex cases including immediate implant placement and immediate loading conditions, using the same concept. In larger studies, the same protocol was used by Babbush and Brokloff ${ }^{23}$ by placing 1001 implants and Graves et al. ${ }^{24}$ by placing 1110 implants and both studies have supported previous studies with a high success rates. In the light of many similar studies, the clinical success of the All-on-4 treatment concept is well documented in the literature and is considered to be a predictable technique with a very good prognosis. Moreover, the majority of the patients were satisfied with this treatment concept, according to the results of the studies that investigate the effect of the All-on-4 treatment concept on the quality of life of the patients. ${ }^{25}$

One of the main advantages of All-on-4 concept is the use of the existing bone in the anterior region instead of the posterior region where the effects of bone resorption are felt more intensely for the both jaws. ${ }^{4,6,14}$ However, bone augmentation methods or zygoma implants are inevitable for patients who do not have sufficient bone volume in the anterior region of their jaws. ${ }^{15,16}$

Many studies on zygoma implants have reported high success rates, low complication rates and even high patient satisfactions. ${ }^{15,16}$ However, the procedure is rather frightening for some patients, even if they are operated under deep sedation or general anesthesia, it does not make it easy for them to accept this operation in the first place. Indeed, in our case where all treatment options have been discussed in detail, or even the treatment options have been explained in the context of visual animations, the patient is not in any way in favor of this option. Conventional ${ }^{12-14}$ implant placement after bone grafting procedures obtained from anterior iliac and maxillary sinus liftings was not found to be acceptable for both the financial and the spiritual sides. As a more minimally invasive method than the other options, the semi-mobile systems such as locator - ball attachments or dolder bar applications, also not accepted by patient under any circumstances, citing the presence of her gag reflex. Therefore, fixed hybrid prosthesis was chosen for the treatment. Although, there are different types of fixed hybrid prostheses (denture teeth processed to a metal framework with pink acrylic; tooth and tissue colored porcelain layered and fused to a metal framework; a milled zirconia framework with layered porcelain or a milled zirconia framework with full contour teeth) ${ }^{26}$, due to acrylic material is more prone to wear porcelain fused to metal framework was preferred to obtain esthetics. In this case, base metal alloys were preferred for the framework construction because Lav et $\mathrm{a}^{27}$ reported that cobalt-chromium frameworks generate least amount of strain on the implants.

In parallel with the widespread use of dental implants, the frequency of graft applications is increasing and techniques are developing. The success of dental implants placed to grafted sites proved in many studies. Among grafting methods, autogenous bone grafting procedures are still considered to be the golden standard. The mandibular symphysis area among the intraoral autogenous graft donor sites is one of the most preferred sites. It has the advantages of easy access to the area, often enough bone grafting, and a relatively safe anatomical work area. ${ }^{28}$ However, especially in the presence of mandibular anterior teeth, dental necrosis in the region and the risk of numbness are among the disadvantages of this practice. ${ }^{29}$ In our case, the mandibular anterior region was chosen since the region is completely edentulous, CBCT examinations show that the area is not only sufficient as donor site but also implant placement in the later stage, and besides bilateral access will be required for the other alternative donor site, the ramus region which was already thin for the patient.

Despite the proven success of implants placed in grafted areas, the number of case reports or studies carried out in the long-term follow-up of All-on-4 concept in the grafted regions in the literature is very small. The main purpose of this case report is to present a 2-year follow-up of $4 \mathrm{imp}$ lants placed to grafted maxilla according to the All-on-4 concept. All-on-4 treatment provided advantages, it provided advantages for the patient such as financial, shortened arc concept, esthetic fixed restorations using pink and white porcelain, with the splinted implants the load is divided to all of the implants in a jaw. ${ }^{4-6,14}$ Multidisciplinary treatment consisting surgical and prosthetic treatment of a patient provided the success. During the follow up period, implant failure, screw loosening, chipping, periimplantitis or difficulty in oral hygiene were not noted in the patient. The radiographic evaluation was made following the prostheses delivering appointment and after 2 years evaluation period. In our case, there was no complication in follow-up of the patient for 2 years and the radiographic evaluation revealed that there was no bone loss in the periimplant bones except physiologically accepted levels. The biggest shortcoming of case reports is the reporting of outcomes of treatments on one or more patients. Therefore, this concept, which still has some controversy, such as the necessity of 2 additional vertical implants (All on Six) to All-on-4 application in maxilla, still needs a wider range of long-term follow-up studies to ensure safe application, especially in grafted areas.

\section{REFERENCES}

1. Branemark PI. Vital microscopy of bone marrow in rabbit. Scand J Clin Lab Invest 1959; 11(38):1-82.

2. Babbush CA, Hahn JA, Krauser JT, Rosenlicht JL. Dental Implants: The Art and Science. 2nd ed: Saunders; 2010. 544 p. 
3. Misch CE. Contemporary Implant Dentistry. 3rd ed: Mosby, Elsevier; 2007. 1120 p.

4. Malo $P$, de Araujo Nobre M, Lopes A, Ferro A, Gravito I. All-on-4(R) Treatment Concept for the Rehabilitation of the Completely Edentulous Mandible: A 7-Year Clinical and 5-Year Radiographic Retrospective Case Series with Risk Assessment for Implant Failure and Marginal Bone Level. Clin Implant Dent Relat Res 2015; 17(2): e531-541. 5. Malo P, de Araujo Nobre M, Lopes A, Francischone C, Rigolizzo M. "All-on-4" immediate-function concept for completely edentulous maxillae: a clinical report on the medium (3 years) and long-term (5 years) outcomes. Clin Implant Dent Relat Res 2012; 14 (1): e139-150.

6. Soto-Penaloza D, Zaragozi-Alonso R, Penarrocha-Diago $\mathrm{M}$, Penarrocha-Diago $\mathrm{M}$. The all-on-four treatment concept: Systematic review. J Clin Exp Dent 2017; 9: e474-488.

7. Malo $P$, Rangert B, Nobre M. "All-on-Four" immediate-function concept with Branemark System implants for completely edentulous mandibles: a retrospective clinical study. Clin Implant Dent Relat Res 2003; 5(1): 2-9.

8. Clelland NL, Gilat A, McGlumphy EA, Brantley WA. A photoelastic and strain gauge analysis of angled abutments for an implant system. Int J Oral Maxillofac Implants 1993; 8: 541-548.

9. Bellini CM, Romeo D, Galbusera F, Agliardi E, Pietrabissa $R$, et al. A finite element analysis of tilted versus nontilted implant configurations in the edentulous maxilla. Int $\mathrm{J}$ Prosthodont 2009; 22: 155-157.

10. Baggi L, Pastore S, Di Girolamo M, Vairo G. Implant-bone load transfer mechanisms in complete-arch prostheses supported by four implants: a three-dimensional finite element approach. J Prosthet Dent 2013; 109: 9-21.

11. Babbush CA, Kanawati A, Kotsakis GA, Hinrichs JE. Patient-related and financial outcomes analysis of conventional full-arch rehabilitation versus the All-on-4 concept: a cohort study. Implant Dent 2014; 23: 218-224.

12. Malo $P$, Rangert $B$, Nobre M. All-on-4 immediate-function concept with Branemark System implants for completely edentulous maxillae: a 1-year retrospective clinical study. Clin Implant Dent Relat Res 2005; 7(1): 88-94.

13. Tan WL, Wong TL, Wong MC, Lang NP. A systematic review of post-extractional alveolar hard and soft tissue dimensional changes in humans. Clin Oral Implants Res 2012; 23 (5)5: 1-21.

14. Chan $\mathrm{MH}$, Holmes C. Contemporary "All-on-4" concept. Dent Clin North Am 2015; 59: 421-470.

15. Chrcanovic BR, Albrektsson T, Wennerberg A. Survival and Complications of Zygomatic Implants: An Updated Systematic Review. J Oral Maxillofac Surg 2016; 74 : 1949-1964.

16. Aparicio $C$, Manresa $C$, Francisco K, Claros $P$, Alandez J, et al. Zygomatic implants: indications, techniques and outcomes, and the zygomatic success code. Periodontol 2000 2014; 66: 41-58.

17. Bellini CM, Romeo D, Galbusera F, Taschieri S, Raimondi MT, et al. Comparison of tilted versus nontilted implant-supported prosthetic designs for the restoration of the edentuous mandible: a biomechanical study. Int J Oral Maxillofac Implants 2009; 24: 511-517.

18. Aparicio $C$, Perales $P$, Rangert $B$. Tilted implants as an alternative to maxillary sinus grafting: a clinical, radiologic, and periotest study. Clin Implant Dent Relat Res 2001; 3: 39-49.

19. Krekmanov L, Kahn M, Rangert B, Lindstrom $H$. Tilting of posterior mandibular and maxillary implants for improved prosthesis support. Int J Oral Maxillofac Implants 2000; 15: 405-414.

20. Malo P, de Araujo Nobre M, Lopes A, Moss SM, Molina GJ. A longitudinal study of the survival of All-on-4 implants in the mandible with up to 10 years of follow-up. J Am Dent Assoc 2011; 142: 310-320.

21. Galindo DF, Butura CC. Immediately loaded mandibular fixed implant prostheses using the all-on-four protocol: a report of 183 consecutively treated patients with 1 year of function in definitive prostheses. Int J Oral Maxillofac Implants 2012; 27: 628-633.

22. Babbush CA, Kutsko GT, Brokloff J. The all-on-four immediate function treatment concept with NobelActive implants: a retrospective study. J Oral Implantol 2011; 37: 431-445.

23. Babbush CA, Brokloff J. A single-center retrospective analysis of 1001 consecutively placed Nobel Active implants. Implant Dent 2012; 21: 28-35.

24. Graves $S$, Mahler BA, Javid B, Armellini D, Jensen OT. Maxillary all-on-four therapy using angled implants: a 16-month clinical study of 1110 implants in 276 jaws. Oral Maxillofac Surg Clin North Am 2011; 23: 277-287.

25. Babbush CA. Posttreatment quantification of patient experiences with full-arch implant treatment using a modification of the OHIP-14 questionnaire. J Oral Implantol 2012; 38: 251-260.

26. Kois Center L. Implant supported bridge with fixed/ detachable (hybrid) components 2016 [24/12/2017]. Available from: http://www.miafitzgerald.com/wp-content/uploads/2017/10/Implant-Supported-Bridge-with-Fixed-Detachable-Hybrid-Components.pdf.

27. Law C, Bennani V, Lyons K, Swain M. Influence of implant framework and mandibular flexure on the strain distribution on a Kennedy class II mandible restored with a long-span implant fixed restoration: a pilot study. J Prosthet Dent 2014; 112: 31-37.

28. Aloy-Prosper A, Penarrocha-Oltra D, Penarrocha-Diago M. The outcome of intraoral onlay block bone grafts on alveolar ridge augmentations: a systematic review. Med Oral Patol Oral Cir Bucal 2015; 20: e251-258. 
29. Reininger $D$, Cobo-Vazquez $C$, Monteserin-Matesanz M, Lopez-Quiles J. Complications in the use of the mandibular body, ramus and symphysis as donor sites in bone graft surgery. A systematic review. Med Oral Patol Oral Cir Bucal 2016; 21: e241-249. 